STUDIA PRAWNO-EKONOMICZNE, T. CVI, 2018

PL ISSN 0081-6841; $\quad$ e-ISSN 2450-8179 $\quad$ s. 29-53

https://doi.org/10.26485/SPE/2018/106/2

\title{
O DESKRYPTYWNYM POZIOMIE INTERPRETACJI TEKSTU PRAWNEGO
}

\section{(Streszczenie)}

Celem artykułu jest analiza wypracowanej przez Ryszarda Sarkowicza koncepcji poziomowej interpretacji tekstu prawnego. Teoria ta $\mathrm{z}$ jednej strony trafnie jest wskazywana jako jedno z bardziej oryginalnych i cennych dokonań polskiej teorii prawa, z drugiej zaś - nieco paradoksalnie - jest ona niezwykle rzadko dyskutowana. W swoim artykule pokazuję pewną niejasność, jaka wkrada się do opisu tego, co R. Sarkowicz nazywa deskryptywnym poziomem interpretacji. Otóż wydaje się, że poziom ten czasami wiązany jest tylko z perspektywą zewnętrzną, a czasami z zewnętrzną i wewnętrzną. W kolejnych podrozdziałach przedstawiam argumenty przemawiające na rzecz zasadności przyjęcia drugiego ze wskazanych ujęć. W konkluzji artykułu pokazuję konsekwencję wyboru takiego rozwiązania. Polega ona na przekształceniu koncepcji poprzez wyróżnienie dodatkowego poziomu interpretacyjnego - deskryptywnego w perspektywie wewnętrznej.

Słowa kluczowe: Ryszard Sarkowicz; poziomy interpretacji tekstu prawnego; wewnętrzny punkt widzenia

\section{Wstęp}

Z wypracowaną przez Ryszarda Sarkowicza koncepcją poziomowej interpretacji tekstu prawnego ${ }^{1}$ łączy się pewien paradoks. Otóż z jednej strony teoria ta

\footnotetext{
Dr, Uniwersytet Wrocławski, Wydział Prawa, Administracji i Ekonomii, Katedra Teorii i Filozofii Prawa; e-mail: pawel.jablonski@uwr.edu.pl

1 R. Sarkowicz, Poziomowa interpretacja tekstu prawnego, nakładem Uniwersytetu Jagiellońskiego, Kraków 1995; idem, Levels of Interpretation of a Legal Text, Ratio Juris, March 1995/8/1, s. 104-112; idem, O rozumieniu spójności w interpretacji prawniczej, w: Teoria prawa. Filozofia prawa. Wspótczesne prawo i prawoznawstwo, Wydawnictwo Uniwersytetu Mikołaja Kopernika, Torun 1998, s. 263-271. Między wersją koncepcji przedstawioną we wskazanej wyżej książce a wersją wyłożoną w przytoczonym artykule anglojęzycznym istnieją fundamentalne różnice. Ze względu na ograniczone ramy mojego tekstu w swoich analizach nie będę tematyzował tych odmienności i oprę się przede wszystkim na wersji książkowej, traktując ją jako podstawową.
} 
zaliczana jest do najbardziej oryginalnych dokonań polskiej ogólnej refleksji o prawie i jako taka cieszy się zasłużonym uznaniem wśród rodzimych badaczy. Wskazuje się mianowicie, że stanowi ona istotny wkład do rozwoju wiedzy o wykładni prawa, mający znaczenie nie tylko teoretyczne, lecz również praktyczne ${ }^{2} . Z$ drugiej jednak strony, mimo upływu ponad dwudziestu lat od jej opublikowania, nie była ona w naszej literaturze szeroko dyskutowana, a ilość dotyczących jej komentarzy jest zaskakująca nieliczna.

Celem niniejszego artykułu jest przyjrzenie się temu, co R. Sarkowicz określa jako deskryptywny poziom interpretacji tekstu prawnego. Ponieważ będę wskazywał na pewne wątpliwości, jakie nasuwają się w rozumieniu tego elementu koncepcji, to od razu chciałbym sformułować trzy uwagi odsłaniające kierunek prowadzonych rozważań. Po pierwsze, niniejszy tekst jest pisany z pozycji zdecydowanego sympatyka omawianej teorii wykładni, który lekturę Poziomej interpretacji tekstu prawnego zalicza do swoich najciekawszych i najważniejszych dla własnego myślenia o prawie doświadczeń czytelniczych. Po drugie, warto w interesującym mnie kontekście przypomnieć wątpliwość zgłoszoną przez Zygmunta Ziembińskiego, recenzującego rzeczoną książkę, który to autor pisał, że „niezbyt łatwo jest pojąć, na czym miałaby polegać «wykładania na poziomie deskryptywnym»"3. Jakkolwiek trudno się zgodzić ze sformułowanym następnie przez poznańskiego teoretyka poglądem, jakoby poziom deskryptywny miał najprawdopodobniej polegać na „określeniu świata realnego, tak jak go widział «prawodawca»"4, to trzeba przyznać, że pewna dezorientacja co do tego, jak dokładnie należy rozumieć ten poziom, wydaje się uzasadniona. W moim przekonaniu źródłem pojawiających się kłopotów z odtworzeniem tego elementu koncepcji jest - co notuję jako trzecią z zapowiedzianych uwag - wkradnięcie się pewnego elementu braku stabilności do jego charakterystyki. Będę więc starał się pokazać, na czym owa niestabilność polega, a także zaproponuję pewien sposób jej przezwyciężenia. Prowadzić to będzie do swoistej rehabilitacji poziomu deskryptywnego. Jakkolwiek bowiem autor koncepcji pisze o nim, że ma ograniczoną wartość

2 Z. Ziembiński, Ryszard Sarkowicz: Poziomowa interpretacja tekstu prawnego (recenzja), Państwo i Prawo 1995/9, s. 92; M. Zieliński, Wykładnia prawa. Zasady, reguły, wskazówki, Wolters Kluwer, Warszawa 2010, s. 91.

Z. Ziembiński, Ryszard Sarkowicz..., s. 91.

4 Ibidem. Dokładniej mówiąc, trudno się zgodzić, że tak to przedstawia R. Sarkowicz w pracy Poziomowa interpretacja tekstu prawnego. Rozpoznanie to wydaje się natomiast dobrze pasować do wersji wyłożonej we wskazanym wyżej artykule anglojęzycznym. 
praktyczną, a samo jego wyodrębnienie „było spowodowane wymogami natury teoretycznej" ${ }^{5}$, to istotność tego poziomu okazuje się - jeśli poniższe rozważania są poprawne - nie mniejsza od pozostałych dwóch.

\section{Poziomowa interpretacja tekstu prawnego - pierwsze spojrzenie}

Pomysł wyodrębnienia różnych poziomów interpretacji tekstu prawnego zaczerpnięty jest $\mathrm{z}$ tradycji hermeneutyki biblijnej i literackiej. ${ }^{6}$ W koncepcji R. Sarkowicza mamy zatem do czynienia z programowym, bardzo atrakcyjnym przeszczepieniem do prawoznawstwa sposobu myślenia wyrosłego na gruncie „sąsiednich” dyscyplin. Jak jednak zauważa Maurycy Zajęcki, pewne tropy „podprowadzające” do trójpoziomowego ujęcia wykładni można również znaleźć poza wskazanymi nurtami

5 R. Sarkowicz, Poziomowa ..., s. 176.

6 Ibidem, s. 6, 27, 62-69.

7 Zob.: M. Zajęcki, Presupozycje surowe i presupozycje instytucjonalne. Próba poszerzenia koncepcji presupozycji tekstu prawnego Marka Smolaka, Ruch Prawniczy, Ekonomiczny i Socjologiczny 2013/2, s. 267, 269. Do autorów wskazanych przez M. Zajęckiego (Jerzy Wróblewski, Tadeusz Buksiński i Jürgen Habermas) należy jeszcze dodać Leona Petrażyckiego, który dość szeroko pisał o możliwości rekonstruowania rzeczywistych stosunków gospodarczych na podstawie analizy prawa - zob. L. Petrażycki, Wstęp do nauki polityki prawa, opracował W. Leśniewski, Państwowe Wydawnictwo Naukowe, Warszawa 1968, s. 156-159. Co więcej, Petrażycjański projekt polityki prawa może być postrzegany jako swoiste odwrócenie procedury rekonstruowania presupozycji. Punktem wyjścia realizacji takiej polityki jest bowiem wypracowanie wiarygodnej koncepcji człowieka i społeczeństwa, a następnie konstruowanie rozwiązań normatywnych bazujących na tej wiedzy. Ciekawy, „Petrażycjański z ducha" przykład współczesnego postępowania, łączącego elementy rekonstrukcji założeń ukrytych w prawie oraz proponowania rozwiązań legislacyjnych wykorzystujących aktualny stan wiedzy naukowej znajdujemy w: R. Zyzik, Obraz człowieka w teorii oświadczeń woli. Perspektywa neuronauki poznawczej i psychologii, Wydawnictwo WAM, Kraków 2016. Wracając zaś do historycznych prekursorów tematyzacji presupozycji prawa, warto jeszcze wspomnieć o Juliuszu Makarewiczu twierdzącym, że ,prawo karne jest jakby fotografią ustroju politycznego i stosunków społecznych, panujących w danej chwili w danym społeczeństwie" (J. Makarewicz, Prawo karne i prawa obywatela, odczyt wygłoszony dnia 20 stycznia w Auli Uniwersytetu Jana Kazimierza we Lwowie, podaję za: I. Zgoliński, Zniesławienie w polskim prawie karnym. Zagadnienia teorii i praktyki, Wolters Kluwer, Warszawa 2013, s. 69-70). Wśród prekursorów takiego sposobu tematyzowania prawa miejsce należy się również Markowi Zirk-Sadowskiemu, który na początku lat osiemdziesiątych minionego wieku pisał o zadaniu dokonania rekonstrukcji koncepcji człowieka wyłaniającej się z obowiązujących przepisów prawnych (M. Zirk-Sadowski, Hermeneutyka a problemy filozofii prawa, Studia Prawno-Ekonomiczne 1982/XXIX, s. 21). Zob. też: E.-W. Böckenförde, Wizerunek człowieka w świetle dzisiejszego porządku prawnego, tłum. M. Łukasiewicz, w: K. Michalski (red.), Człowiek w nauce współczesnej. Rozmowy z Castelgandolfo, ÉDITIONS DU DIALOGUE, Paryż 1988, s. 115-125. 
Przypomnijmy, że tekst prawny ujmowany jest w interesującej nas koncepcji - za Maciejem Zielińskim - jako zbiór wszystkich aktów prawnych obowiązujących $\mathrm{w}$ określonym miejscu i czasie ${ }^{8}$. Przez poziomy interpretacyjne R. Sarkowicz rozumie z kolei odmienne, dopełniające się sposoby czytania aktów prawnych:

W przypadku każdego z nich interpretator co innego widzi w tekście prawnym, czym innym się interesuje i inne napotyka problemy. Każde z tych trzech podejść wymaga od interpretatora innego rodzaju zabiegów interpretacyjnych i prowadzi do odmiennego odczytania tekstu. Każde takie odmienne odczytanie tekstu pozwala przypisać właściwą mu wizję świata9 .

Podkreślmy, że kryterium wyodrębnienia poziomu jest nie tyle jakaś wewnętrzna właściwość samego tekstu, ile typ podejścia interpretacyjnego oraz wyniki, jakie on przyniesie:

Poziomy interpretacyjne to zatem nie coś, co tkwi immanentnie w tekście i istniałoby niezależnie od interpretatora, lecz coś, co dzięki aktywności interpretacyjnej interpretatora zostaje wyodrębnione z tekstu i uporządkowane wedle pewnych reguł, różnych dla każdego poziomu interpretacyjnego ${ }^{10}$.

To bardzo ważny moment, ponieważ zdaje się on przesądzać o tym, że ocena zasadności wyodrębnienia poszczególnych poziomów czy też ich kompletności zależy od rozpoznania określonych rodzajów „poznawczej uwagi” podmiotu. Ewentualnie - nieco ostrożniej i chyba bliżej intencji R. Sarkowicza - chodziłoby o swoistą wypadkową rodzajów tej uwagi z jednej strony, a rozsądnych możliwości, jakie stwarza tekst prawny, z drugiej.

Jak wiadomo, R. Sarkowicz wyróżnia trzy poziomy interpretacyjne: deskryptywny, dyrektywny i presupozycjonalny. O pierwszym z nich czytamy:

Poziomem deskryptywnym interpretacji tekstu prawnego będziemy określać opisową, wyrażoną bezpośrednio w języku, warstwę tekstu prawnego. Obejmuje on zatem opis osób, rzeczy, zdarzeń, zachowań, itp., należących do pewnego świata, o którym mówi tekst prawny. Jest to zatem opis pewnego świata, którego wizję wytwarza sobie interpretator w trakcie bezpośredniego, literalnego, dosłownego studiowania języka tekstu ${ }^{11}$.

Poziom deskryptywny polega więc na informacyjnym czytaniu tekstu prawnego - uwaga ukierunkowana jest na odtworzenie elementów świata, o którym tekst opowiada.

8 R. Sarkowicz, Poziomowa ..., s. 55, 58; idem, O rozumieniu ..., s. 265.

Idem, Poziomowa ..., s. 64.

Idem, $O$ rozumieniu..., s. 265.

1 Idem, Poziomowa ..., s. 67. 
Poziom dyrektywny z kolei łączy się z konstrukcją wynikających z tekstu dyrektyw, w szczególności zaś norm prawnych. W tym zakresie R. Sarkowicz włącza do swojego ujęcia derywacyjną koncepcję wykładni, wypracowaną przez M. Zielińskiego ${ }^{12}$. Mimo kilku modyfikacji ujęcia derywacyjnego dokonanych przez krakowskiego teoretyka na potrzeby adaptacji do własnych rozważań, koncepcja derywacyjna jest istotnym elementem teorii wykładni poziomowej ${ }^{13}$. Przejście od poziomu deskryptywnego do dyrektywnego polega na przekształcaniu przepisów prawnych w normy prawne ${ }^{14}$, zaś świat poziomu dyrektywnego to rozpadający się na dwa odmienne światy - norm sankcjonowanych i norm sankcjonujących - „idealny” świat powinności ${ }^{15}$.

O ostatnim z poziomów czytamy:

Poziom presupozycji tekstu prawnego to głębszy poziom interpretowanego tekstu, do którego z reguły dociera się poprzez analizę poziomu deskryptywnego $i-w$ nieco mniejszym stopniu - poziomu dyrektywnego. Obejmuje on wszelkie informacje o współczesnym dla prawodawcy świecie, społeczeństwie, człowieku, jego poglądach i wartościach, informacje, jakie możemy odtworzyć z tekstu prawnego. Informacje te dotyczą więc pewnej całościowej wizji świata opartej na wiedzy posiadanej przez prawodawcę w okresie tworzenia tekstu prawnego. Wszelkie te informacje nie są wyrażone bezpośrednio w tekście prawnym, ale jego wypowiedzi je presuponują ${ }^{16}$.

Poziom ten polega zatem na rekonstrukcji wizji świata, jaką zdaje się przyjmować prawodawca. Jak pisze R. Sarkowicz, praca ta przypomina swoiste kom-

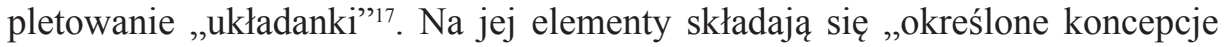
przyrodnicze, filozoficzne, religijne, społeczno-ekonomiczne, ustrojowo-polityczne ujęte w pewien, mniej lub bardziej spójny i ogólny system"18. Krakowski teoretyk mocno przy tym podkreśla, że presupozycjonalny poziom interpretacji dostarcza wiedzy „nie o jakimś świecie możliwym, wykreowanym przez prawodawcę, lecz o świecie rzeczywiście istniejącym"19.

Trzeba podkreślić, że każdy poziom prowadzi do rekonstrukcji innego świata związanego z tekstem prawnym. Dla przejrzystości rozważań przyjmijmy, że na poziomie deskryptywnym odtwarzamy pierwszy świat (ś1), na dyrektywnym - drugi ('s2), zaś na presupozycjonalnym - trzeci (ś3). Ś1 to świat bytów

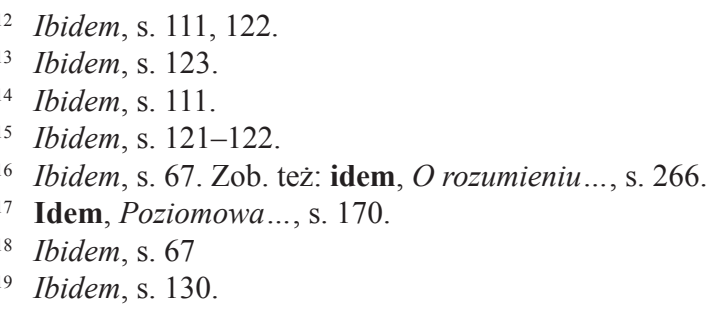


prawnych czy też - jak trafnie określa to M. Zajęcki - ,świat konstruktów prawnych"20. Ś2 to idealny świat powinności, w którym każdy robi to, co powinien, zaś ś3 - świat realny ${ }^{21}$.

Odnotujmy jeszcze dwie uwagi porządkujące. Po pierwsze, istnieje pokusa, by uznać, że nie tylko ś2, lecz również ś1 ma charakter idealny, mianowicie idealny w znaczeniu ontologicznym. Ujęcie takie wydaje się dobrze przystawać do koncepcji trzeciego świata Karla Poppera ${ }^{22}$. Ponieważ jednak R. Sarkowicz wyraźnie stwierdza, że nie przyjmuje rozstrzygnięć ontologicznych w swojej teorii, więc i my tutaj powstrzymamy się od rozwijania tego wątku.

Po drugie, bardzo ważnym elementem analizowanej koncepcji jest kolejność dokonywanych interpretacji. Otóż jakkolwiek istnieje tutaj zasadniczy kierunek „głębinowy”, tj. od poziomu deskryptywnego, poprzez dyrektywny, do presupozycji, to w odniesieniu do poziomów opisowego i dyrektywnego czytamy, że ,poprawniejsze ujęcie procesu interpretacji obu tych poziomów stanowi wizja naprzemiennego, coraz to precyzyjniejszego odtwarzania elementów obu tych poziomów przez interpretatora" ${ }^{23}$. Wydaje się, że taki dwukierunkowy ruch należy także przyjąć między poziomem dyrektywnym a poziomem presupozycji, inaczej bowiem trudno byłoby zrozumieć, w jaki sposób rozpoznanie presupozycji wpłynąc ma na stosowanie prawa ${ }^{24}$. Wśród teoretyków analizujących interesującą nas tu koncepcję nie ma zgody co do proporcji udziału poziomów deskryptywnego i dyrektywnego w rekonstruowaniu presupozycji. Jak widać w przytoczonych wyżej słowach, krakowski teoretyk przyjmuje, że presupozycje odtwarzane są w większym stopniu z poziomu deskryptywnego, a w mniejszym z dyrektywnego. Tak samo rzecz ujmuje Marek Smolak ${ }^{25}$. Natomiast Maurycy Zajęcki twierdzi, że warstwa dyrektywna odgrywa tutaj znacznie ważniejszą rolę niż deskryptywna ${ }^{26}$.

20 Zob.: M. Zajęcki, Presupozycje tekstu jako narzędzie analizy w naukach historycznoprawnych $i$ w teorii prawa, w: P. Orlik, K. Przybyszewski (red.), Filozofia a sfera publiczna, Wydawnictwo Naukowe Instytutu Filozofii, Poznań 2012, s. 74.

21 Zob.: R. Sarkowicz, Poziomowa ..., s. 122; idem, O rozumieniu ..., s. 266.

22 Zob.: K.R. Popper, Wiedza a zagadnienie ciała i umystu. W obronie interakcji, thum. T. Baszniak, Książka i Wiedza, Warszawa 1998, s. 24-38.

23 R. Sarkowicz, Poziomowa ..., s. 67.

24 Zob.: M. Zajęcki, Presupozycje tekstu..., s. 90.

25 M. Smolak, Presupozycje ontologiczne tekstu prawnego, Ruch Prawniczy, Ekonomiczny i Socjologiczny 2011/4, s. 44-45.

26 Zob.: M. Zajęcki, Presupozycje surowe..., s. 271. 
W ślad za Ryszardem Sarkowiczem warto przy tym podkreślić, że teza o naprzemiennym odtwarzaniu różnych poziomów przez interpretatora nie powinna przesłaniać twierdzenia o rekonstruowaniu różnych światów na każdym z nich. Nie należy więc mylić wzajemnego odsyłania do siebie poszczególnych poziomów z konstruowaniem jednej, wspólnej wizji świata ${ }^{27}$.

\section{Czy istnieje internalna perspektywa deskryptywnego poziomu interpretacji tekstu prawnego?}

Wstępny obraz działania, jakie należy wykonać przy przyjęciu perspektywy wyznaczanej przez koncepcję poziomowej interpretacji tekstu prawnego, wydaje się jasny. Trzeba mianowicie przedzierać się przez kolejne warstwy interpretacji ruchem raczej spiralnym niż prostoliniowym, docierając ostatecznie do dokładnego rozpoznania poziomu presupozycji, gdzie dochodzi - jako że jest to poziom najgłębszy - do swoistej kulminacji całego badania. Przy bliższym jednak przyjrzeniu się tej koncepcji sprawy zaczynają się komplikować, a do istoty interesującej mnie kwestii można dojść z dwóch punktów wyjścia.

Pierwszy z nich to zagadnienie zmiany przedmiotu badawczego, jaka ma miejsce przy przejściu do poziomu presupozycji - oto podstawowym tematem przestają być światy z tekstu prawnego (ś1 i ś2), a zaczyna być nim świat, w którym ten tekst funkcjonuje (ś3). A zatem kulminacja badania rzeczywistości prawnej okazuje się być połączona z przekierowaniem uwagi na coś innego. Interpretacja świata, w którym funkcjonuje tekst, jest bowiem czymś odmiennym niż interpretacja świata, który funkcjonuje w tekście. Jakkolwiek światy te mogą być do siebie pod wieloma względami podobne, to ich ontologiczny status jest inny. Oczywiście, mówienie o ,świecie, który funkcjonuje w tekście prawnym" jest pewnego rodzaju uproszczeniem.

Drugi natomiast punkt wyjścia - który wykorzystam w dalszej części artykułu - to sygnalizowany wyżej brak stabilności, jaki wkrada się do ujęcia poziomu deskryptywnego. Chodzi mianowicie o następującą wątpliwość: czy istnieje internalna perspektywa deskryptywnego poziomu interpretacji tekstu prawnego? Otóż wydaje się, że w rozważaniach R. Sarkowicza znaleźć można przesłanki do udzielenia dwóch przeciwnych odpowiedzi na to pytanie. Z jednej strony poziom deskryptywny łączony jest $\mathrm{z}$ eksternalnym punktem widzenia,

27 R. Sarkowicz, Poziomowa ..., s. 67. 
przy czym związek ów wskazywany jest explicite jako istotowa cecha tego poziomu, pozwalająca odróżnić go od poziomu dyrektywnego ${ }^{28}$. Ujęcie to dobrze pasuje do charakterystyki podejścia deskryptywnego jako wyniku poprzestawania na dosłownej, literalnej, powierzchownej lekturze, niewymagającej przygotowania prawniczego ${ }^{29}$. Z drugiej jednak strony nasuwa się kilka dobrych, jak sądzę, powodów, dla których należałoby przyjąć istnienie perspektywy internalnej poziomu deskryptywnego. Argumenty te przedstawiam poniżej, w kolejnych podrozdziałach.

Dla porządku zaznaczmy jeszcze, że mówiąc o rozróżnieniu na perspektywę internalną i eksternalną, R. Sarkowicz nawiązuje do szeroko znanej w teoretycznej refleksji o prawie dystynkcji pojęciowej, wprowadzonej przez Herberta L.A. Harta ${ }^{30}$. Ponieważ jednak - jak trafnie odnotowuje krakowski badacz - dokonany przez autora Pojęcia prawa sposób prezentacji różnicy między perspektywą wewnętrzną a zewnętrzną pozostawia sporo wątpliwości, Sarkowicz opiera się bezpośrednio na zreinterpretowanej wersji tej opozycji, zaproponowanej przez Neila MacCormicka. Przypomnijmy, że MacCormick wyróżnia dwa aspekty wewnętrznego punktu widzenia, tj. poznawczy i wolicjonalny. O poznawczo-internalnym punkcie widzenia mówimy wtedy, gdy mamy do czynienia z należytym rozumieniem określonych standardów lub regul, a więc takim rozumieniem, które opiera się o niezbędne zaplecze kulturowe. O wolicjonalno-internalnym punkcie widzenia mówimy z kolei wtedy, gdy poznawane reguły traktowane są jako swoje własne, $\mathrm{tj}$. gdy dany podmiot czuje się zobowiązany do ich respektowania z innych powodów niż ewentualna groźba sankcji. W przypadku eksternalnego punktu widzenia mamy z kolei do czynienia z taką sytuacją, w której podmiot ani nie potrafi należycie rozpoznać reguł, ani też nie traktuje ich jako zobowiązujących niezależnie od sankcji.

\section{Argument $z$ tekstu}

Kategoryczne przyporządkowanie poziomu deskryptywnego do perspektywy eksternalnej, pojawiające się w ostatnich partiach Poziomowej interpretacji tekstu prawnego, jest zaskakujące $\mathrm{z}$ tego między innymi względu, że we

28 Ibidem, s. 176.

29 Tak o poziomie deskryptywnym pisze też Maciej Zieliński - zob.: M. Zieliński, Wyktadnia prawa..., s. 91.

30 R. Sarkowicz, Poziomowa ..., s. 98-102. 
wcześniejszych częściach książki sprawa wydaje się bardziej złożona. W uwagach zamykających rozdział poświęcony deskryptywnemu poziomowi interpretacji czytamy:

Powstaje jeszcze inne pytanie: Do którego z wyróżnionych powyżej trzech punktów widzenia: a) eksternalnego, b) poznawczo-internalnego, c) wolicjonalnie-internalnego najbardziej może przystawać deskryptywna interpretacja tekstu prawnego. Odpowiedź nie wydaje się trudna, gdyż spośród trzech obserwatorów, z których każdy patrzyłby na reguły prawne zawarte $\mathrm{w}$ tekście prawnym $\mathrm{z}$ jednego $\mathrm{z}$ trzech wymienionych punktów widzenia, tylko jeden z nich jest zdany wyłącznie na niego. Obserwator studiujący reguły z eksternalnego punktu widzenia nie ma innej możliwości ich interpretacji, jak interpretacja deskryptywna. Jednym słowem, dociera ona wyłącznie do poziomu interpretacji deskryptywnej, gdzie tekst stanowi dla niego poznawczo interesujący materiał o pewnym świecie, o którym on opowiada ${ }^{31}$.

Zauważmy, że w wypowiedzi tej zawarta jest implicite informacja o możliwości łączenia interpretacji na poziomie deskryptywnym również z internalnym punktem widzenia. Argument ten nie na to bowiem wskazuje, że tylko dla poznającego prawo z eksternalnego punktu widzenia dostępny jest poziom deskryptywny, lecz na to, że dla niego jest dostępny tylko ten poziom. W dalszej części wywodu R. Sarkowicz pisze zresztą explicite o możliwości interpretacji deskryptywnej prowadzonej z perspektywy poznawczo-internalnej, przy czym za przykład podawany jest tu historyk studiujący poziom opisowy w celu ujawnienia presupozycji ${ }^{32}$.

\section{Argument odwołujący się do procedury interpretacyjnej}

Jak już było wspominane, w koncepcji R. Sarkowicza podkreślana jest potrzeba dwukierunkowego ruchu między poziomem deskryptywnym i dyrektywnym, prowadzącego do naprzemiennego odtwarzania obu tych poziomów. Mamy tu zatem do czynienia $\mathrm{z}$ rekonstruowaniem dwóch różnych światów, $\mathrm{z}$,naprzemiennym, coraz to precyzyjniejszym odtwarzaniu elementów obu tych poziomów przez interpretatora (metoda koła hermeneutycznego)"33. Wydaje się jednak, że wskazywany tu spiralny ruch międzypoziomowy jest właśnie niczym innym niż przyjmowaniem internalnego punktu widzenia. Jeśli poziom dyrektywny dostępny jest tylko dla perspektywy internalnej, to i ów ruch musi zakładać przyjmowanie takiej perspektywy. Z tego wydaje się wynikać nie tylko to, że poziom deskryptywny nie musi być łączony z perspektywą eksternalną, ale

31 Ibidem, s. 110.

32 Ibidem. Zob. też: ibidem, s. 102-106.

33 Idem, O rozumieniu ..., s. 265. Zob. też: idem, Poziomowa ..., s. 67, 124. 
znacznie więcej - że właściwe odtworzenie tego poziomu zakłada perspektywę internalną. Poziom ten byłby zatem czymś dużo ciekawszym i ważniejszym niż tylko wynikiem powierzchownej, literalnej lektury laika. Z tym bezpośrednio łączy się argument kolejny.

\section{Argument odwołujący się do charakterystyki pierwszego świata}

Poziom deskryptywny określany jest nie tylko jako wynik literalnego, „powierzchniowego" odczytania teksu prawnego, lecz również jako „opowieść o pewnym świecie, o którym opowiada nam prawodawca" ${ }^{34}$. R. Sarkowicz pisze, że chodzi tu o opis określonego „możliwego świata” ${ }^{35}$, przy czym - jak już było wspominane - świat ten należy traktować jako pozbawioną roszczeń ontologicznych konstrukcję intelektu ${ }^{36}$. Jak czytamy:

Na tym poziomie nie znajdziemy zatem opisu świata powinnego (to należy zatem do poziomu dyrektywnego), lecz świata pojętego na podobieństwo świata fikcji literackiej zawartej w powieści. Warto to podkreślić, bo stanowi to zdecydowaną różnicę w stosunku do poziomu dyrektywnego interpretacji, do którego należeć będzie konstruowanie innego świata - idealnego świata powinności ${ }^{37}$.

Miarą koherencji poziomu deskryptywnego jest spójność logiczna twierdzeń o wyłaniającym się świecie tekstu oraz spójność narracyjna. Ta ostatnia może jednak przysługiwać jedynie fragmentom tekstu i dlatego też R. Sarkowicz zauważa, iż właściwie bardziej adekwatna byłaby tu metafora prawa jako zbioru opowiadań niż prawa jako powieści ${ }^{38}$.

W celu zilustrowania specyfiki ś1 twórca poziomowej koncepcji wykładni odwołuje się do artykułu Tomasza Gizberta-Studnickiego Język prawny a obraz świata, w którym to tekście przedstawiona jest analiza swoistości świata wyznaczonego przez język prawny ${ }^{39}$. Autor artykułu zwraca uwagę, że w świecie prawa dane doświadczenia są często odmiennie kategoryzowane niż ma to miejsce w „świecie rzeczywistym”, a nadto do krainy prawa wprowadzane są nowe

34 Idem, Poziomowa ..., s. 97.

35 Ibidem, s. 68.

36 Ibidem, s. 96.

37 Ibidem, s. 97. Zob. też: ibidem, s. 109.

38 Idem, O rozumieniu ..., s. 268; Zob. też: idem, Poziomowa ..., s. 56-57.

39 Idem, Poziomowa ..., s. 106-109. Zob. też: T. Gizbert-Studnicki, Język prawny a obraz świata, w: G. Skąpska (red.), Prawo w zmieniajacym się społeczeństwie, Wydawnictwo Adam Marszałek, Kraków 1992, s. 149-161. 
obiekty i kwalifikacje, nieznane poza prawem. T. Gizbert-Studnicki, opisując świat tekstu prawnego, mówi między innymi:

Szczególnie dobitnym przykładem takiej swoistej dla świata prawnego kategoryzacji jest przyjęta w prawie cywilnym klasyfikacja faktów prawnych. Do jednej kategorii zalicza się opierając się na tej klasyfikacji takie zdarzenia, które w potocznym obrazie świata nie mają żadnych cech wspólnych (a więc np. złożenie podpisu na dokumencie, kupno gazety, wejście do tramwaju, zachowanie milczenia w pewnej sytuacji - czynności zmierzające do wywołania skutków prawnych) ${ }^{40}$.

Zauważmy, że dokładne rozpoznanie właściwości świata, o którym pisze T. Gizbert-Studnicki, wymaga wewnętrznego, prawniczego punktu widzenia. Świat ten opisywany z perspektywy zewnętrznej będzie nieuchronnie przedstawiał pewien chaos. Ujmując to od nieco innej strony, ś1 może zostać poprawnie zrekonstruowany tylko z perspektywy wewnętrznej, uwzględniającej dorobek orzecznictwa i doktryny.

\section{Argument odwołujący się do kompletności koncepcji}

Kolejny powód, dla którego należy - jak sądzę - uznać, że poziom deskryptywny łączy się również z internalnym punktem widzenia, odwołuje się do kompletności poziomowego ujęcia interpretacji. Jeśli bowiem przyjąć, że różnica między poziomem deskryptywnym a dyrektywnym uzasadniona jest odmiennością zewnętrznego i wewnętrznego punktu widzenia, to wydaje się, że cała szeroka grupa zagadnień zajmujących interpretatorów tekstów prawnych lokuje się poza problematyką poruszaną na wszystkich poziomach interpretacji. Podajmy trzy przykłady.

Pierwszym z nich jest kwestia dyskutowana w związku z art. 213 kodeksu karnego. W paragrafie pierwszym wskazanego artykułu czytamy, że nie dochodzi do przestępstwa zniesławienia, jeśli zarzut uczyniony niepublicznie jest prawdziwy. W paragrafie drugim natomiast prawodawca stanowi, że nie dopuszcza się zniesławienia również taka osoba, która publicznie podnosi lub rozgłasza prawdziwy zarzut, jeśli zarzut ten bądź to dotyczy osoby pełniącej funkcje publiczne, bądź to służy obronie społecznie uzasadnionego interesu. Otóż w literaturze dogmatycznoprawnej trwa spór o to, czy w podanych przepisach mamy do czynienia z kontratypem, czy też z uściśleniem znamion występku ${ }^{41}$. Uwzględnienie tego sporu wydaje się istotnym elementem charakterystyki frag-

40 T. Gizbert-Studnicki, Język prawny..., s. 157.

41 Zob. I. Zgoliński, Zniestawienie..., s. 162 i n. 
mentu świata tekstu prawnego, który dotyczy zniesławienia. Jak zauważa Igor Zgoliński, pogląd, wedle którego we wskazanym przepisie mamy do czynienia $\mathrm{z}$ dookreśleniem przestępstwa, a nie z kontratypem, skutkuje uznaniem istnienia dwóch odmian zniesławienia zamiast jednego.

W roli drugiego przykładu powołajmy wprowadzone w doktrynie karnistycznej rozróżnienie na cześć wewnętrzną i cześć zewnętrzną. Przyjmuje się mianowicie, że pierwsza $\mathrm{z}$ nich jest dobrem prawnym naruszanym przez zniewagę, zaś druga przez zniesławienie. Jakkolwiek terminy te nie występują w tekście prawnym, to są elementami języka prawniczego niezbędnymi dzisiaj do poprawnego zrekonstruowania tej części świata tekstu prawnego, która łączy się ze wskazanymi wyżej występkami. Opowiadanie o wolności słowa nieuwzględniające tych obiektów ś1 byłoby z konieczności niekompletne.

Trzeci przykład ma charakter bardziej ogólny. Chodzi w nim mianowicie o to, że elementem rozumienia świata tekstu prawnego, by tak rzec - całej jego fizyki opisującej istniejące w nim byty, jest operowanie kategoriami swoistej dogmatycznoprawnej metafizyki, opierającej się na takich pojęciach jak na przykład wspomniany kontratyp czy inne elementy podstawowej siatki terminologicznej danej gałęzi prawa.

Zastanówmy się teraz, na którym z poziomów interpretacji jest miejsce na uwzględnienie wskazanych zagadnień. Jeśli poziom deskryptywny łączymy z perspektywą eksternalną, to oczywiście tutaj nie może być miejsca na poruszanie tych problemów, jako że w ogóle nie są one na nim widoczne. Jednak poszukiwanego miejsca nie ma również na poziomie dyrektywnym. Tutaj bowiem mamy do czynienia z normami (a nie opisem) lub postulowanymi, wzajemnie się wykluczającymi światami idealnymi norm sankcjonowanych i sankcjonujących. A zatem nie ma tu mowy o jednej krainie prawa. Wreszcie, również na poziomie presupozycji trudno znaleźć miejsce dla rekonstrukcji świata prawniczego z perspektywy wewnętrznej. Jeśli bowiem rekonstruowanie presupozycji prowadzi do zmiany przedmiotu zainteresowań, tj. wspomnianego już zastąpienia badania świata, jaki funkcjonuje w tekście prawnym przez badanie świata, w którym funkcjonuje ten tekst, to nie zajmujemy się już tutaj konstruktami prawnymi, lecz społeczno-filozoficznymi warunkami ich powstawania.

Gdzie zatem w koncepcji poziomowej interpretacji tekstu prawnego jest miejsce na internalny opis krainy prawa? Gdzie właściwie następuje kulminacja badania pierwszego z wyżej wskazanych światów? Innymi słowy, gdzie jest miejsce na prawniczą, spójną i optymalizującą rekonstrukcję bytów ze świata wykreowanego przez prawodawcę, czy też - mówiąc dokładniej - wykreowanego w swoistym dialogu, jaki jest prowadzony między prawodawcą 
a prawnikami? Wydaje się, że rozwiązanie tego problemu wymaga dokonania jednego $z$ trzech zabiegów.

Po pierwsze, można rozumieć poziom dyrektywny w taki sposób, by nie ograniczał się on tylko do norm prawnych i światów idealnych. Na korzyść takiego rozwiązania zdają się świadczyć następujące słowa R. Sarkowicza: „wszystkie te czynności, które są podejmowane przez interpretatora w celu zrekonstruowania tych dyrektyw, a w szczególności norm - nazwiemy interpretacją dyrektywalną”42. W innym miejscu czytamy: „Do problematyki tego poziomu należą więc wszystkie kwestie, które wiążą się z ową rekonstrukcją"43. Można więc upatrywać w tym sformułowaniu podstawy do zaliczenia wskazanych wyżej przykładowych zagadnień do problematyki tematyzowanej na poziomie dyrektywalnym. Takie rozwiązanie wydaje się jednak nieprzekonujące z trzech powodów. Najpierw zauważmy, że gdyby przytoczone wypowiedzi rozumieć w ten sposób, to właściwie trzeba by uznać, że cały poziom deskryptywny jest skonsumowany przez dyrektywny, jako że interpretacja deskryptywna jest konieczna dla dyrektywalnej ${ }^{44}$. Co więcej, ponieważ przyjmuje się, że ustalenie presupozycji również może mieć znaczenie dla stosowania prawa, to przynajmniej część z tego poziomu zostałaby również włączona do dyrektywnego. Po wtóre, rozwiązanie uznające przynależność problemów z wskazanych wyżej przykładów do poziomu dyrektywnego skutkowałoby jeszcze większą hybrydyzacją tego poziomu (zawierającego wtedy: normy, światy idealne oraz świat tekstu) i chyba zmniejszeniem przez to przejrzystości całej koncepcji. Innymi słowy ś1 podpadałby wtedy zarazem pod poziom pierwszy i drugi, tyle że na pierwszym byłby niepoprawnie i niewyraźnie odtworzony, zaś poziom drugi obejmowałby jeszcze dodatkowo ś2. Podkreślmy, że formułowany tu argument nie opiera się na błędnym przypuszczeniu, że poziom dyrektywny nie zawiera elementu klarującego (zawiera go bez wątpienia), lecz na ontologicznej różnicy między ś1 i ś2. Kolejny powód odrzucenia tego rozwiązania to wątpliwość, czy wszystkie podane w powyższych przykładach zagadnienia rzeczywiście są niezbędne do rekonstrukcji normy.

Drugim nasuwającym się rozwiązaniem jest ulokowanie wskazanej problematyki na poziomie presupozycji. Aby przyjrzeć się takiej interpretacji koncepcji poziomowej, trzeba najpierw powiedzieć parę słów o rodzajach presupozycji oraz o tym, czego one dokładnie dotyczą.

42 R. Sarkowicz, Poziomowa ..., s. 111.

43 Ibidem, s. 67.

44 Ibidem, s. 124. 
R. Sarkowicz dzieli presupozycje tekstu na trzy rodzaje - ontologiczne (ujmowane bardzo szeroko - jako zdania opisujące fakty dotyczące człowieka i społeczeństwa ${ }^{45}$ ), epistemologiczne i aksjologiczne. Zaznacza przy tym, że drugie z wyżej wymienionych stanowią niewielką część z wszystkich presupozycji, zaś podstawowe znaczenie dla prawnika mają zwykle te, które dotyczą wartości ${ }^{46}$. Co ciekawie, kiedy w 2005 r. R. Sarkowicz nawiązuje do swojej koncepcji, to pisze, że ,prawnik musi dokonać interpretacji w trzech różnych wymiarach: deskryptywnym, dyrektywnym i aksjologicznym"47. Widzimy zatem, że rekonstrukcja presupozycji dotyczących wartości utożsamiana jest tutaj z całym trzecim poziomem interpretacji tekstu prawnego. Zauważalnej tu redukcji poziomu presupozycjalnego do wymiaru aksjologicznego nie należy jednak - jak sądzę - postrzegać jako jakiegoś przekształcenia koncepcji, lecz raczej jako nawiązanie do niej w konkretnym, związanym ściśle ze stosowaniem prawa kontekście, w którym presupozycje dotyczące wartości są najistotniejsze.

R. Sarkowicz wyodrębnia dwa typy presupozycji, tj. silne (spełniające test odporności na negację) oraz słabe (takie, które nie spełniają tego testu). Presupozycje słabe mają więc nie tyle charakter semantyczny, ile pragmatyczny, funkcjonują one jako dające się rozsądnie zrekonstruować założenia ${ }^{48}$. Twórca koncepcji interpretacji poziomowej konstatuje przy tym, że o ile presupozycje ontologiczne mają często charakter mocny, o tyle presupozycje aksjologiczne zwykle są słabe ${ }^{49}$.

R. Sarkowicz wskazuje, że odnosząc problematykę rekonstrukcji presupozycji do kwestii upływu czasu, można wyróżnić dwa podejścia, z których pierwsze łączy się ze statyczną, zaś drugie z dynamiczną teorią wykładni ${ }^{50}$. W pierwszym ujęciu celem rekonstrukcji presupozycji jest odtworzenie właściwości świata,

45 Ibidem, s. 160-164. Marek Smolak w interesującym opracowaniu prezentuje stanowisko, wedle którego znaczna część rzeczywistości zakładanej w presupozycjach ontologicznych tekstu prawnego ma charakter instytucjonalny - zob.: M. Smolak, Presupozycje ontologiczne..., s. 41-51. Zob. też: M. Zajęcki, Presupozycje surowe..., s. 265-279 oraz M. Smolak, Kilka uwag do artykułu Maurycego Zajęckiego „Presupozycje surowe i instytucjonalne: Próba poszerzenia koncepcji presupozycji tekstu prawnego Marka Smolaka”, Ruch Prawniczy, Ekonomiczny i Socjologiczny 2013/LXXV/2, s. 281-284.

46 R. Sarkowicz, O rozumieniu ..., s. 266; idem, Poziomowa..., s. 159, 164-169.

47 Idem, Uwagi o wspótczesnej interpretacji prawniczej, w: S. Wronkowska (red.), Polska kultura prawna a proces integracji europejskiej, Zakamycze 2005, s. 23.

48 R. Sarkowicz, Poziomowa ..., s. 140-145.

49 Ibidem, s. 171.

50 Ibidem, s. 173-174. Zob. też: A. Bator, Poziomowa interpretacja tekstu prawnego, w: idem (red.), Wprowadzenie do nauk prawnych. Leksykon tematyczny, Wolters Kluwer, Warszawa 2016, s. 280-284. 
w którym powstawał tekst prawny. Część z takich presupozycji ma charakter szybko dezaktualizujący się, inne zaś trwają bardzo długo, pozwalając przez to wyodrębnić określone epoki w europejskiej kulturze prawnej ${ }^{51}$. Ujmując rzecz ściślej, poziom presupozycji dostarcza tu nie tyle informacji o jakimś rzeczywistym świecie, ile o sposobie jego widzenia przez prawodawcę ${ }^{52}$. Jak czytamy, w przypadku presupozycji ontologicznych można przyjąć, że wizja ta z reguły dość dobrze odzwierciedla samą tę rzeczywistość. W przypadku presupozycji aksjologicznych sprawa jest już bardziej złożona. R. Sarkowicz zwraca uwagę, że aby przyjąć, iż aksjologia presuponowana w tekście prawnym jest lub była reprezentatywna nie tylko dla prawodawcy, lecz również dla większości członków danego społeczeństwa, potrzebne są jakieś dodatkowe argumenty. Mogą one być dostarczone przez innego rodzaju badania, np. historyczne, archeologiczne czy socjologiczne. Mogą one jednak pochodzić również z samego prawoznawstwa - jak wskazuje Sarkowicz, istnienie przepisów ustanawiających demokrację przedstawicielską zwiększa szanse społecznej reprezentatywności aksjologii prawodawcy ${ }^{53}$. Ciekawej ilustracji, mogącej skłaniać do pewnych wątpliwości związanych z korespondencją między ontologicznymi presupozycjami przypisywanymi prawodawcy a współczesną mu rzeczywistością, dostarcza rozprawa Leona Petrażyckiego. W Polityce prawa cywilnego i ekonomii politycznej spotykamy mianowicie doskonale wpisujące się w koncepcję poziomowej interpretacji porównanie pracy socjologów rekonstruujących stosunki społeczne w oparciu o badanie tekstów prawnych, do analizy wykonywanej przez biologów, którzy „na podstawie wykopanych niewielkich szczątków, na przykład uzębienia prehistorycznego zwierzęcia, są w stanie z przybliżoną dokładnością zrekonstruować anatomię całego zwierzęcia"s4. Otóż, odnosząc taką perspektywę do krytykowanego przez siebie niemieckiego projektu kodeksu cywilnego, Petrażycki stawia zarzut, że jest on zlepkiem różnych, nieprzystających do siebie obrazów rzeczywistości ${ }^{55}$. A zatem rekonstrukcja presupozycji ontologicznych w tym wypadku nie tylko nie zapewniłaby odtworzenia prawdziwego obrazu rzeczywistości, ale nawet nie doprowadziłaby do zbudowania jednego, spójnego obrazu.

51 R. Sarkowicz, Poziomowa ..., s. 171-172.

52 Ibidem, s. 160. Por.: ibidem, s. 155-156.

53 Ibidem, s. 151-169.

54 L. Petrażycki, Polityka prawa cywilnego i ekonomia polityczna, thum. P. Kosiński, redakcja naukowa, wstęp i uwspółcześnienie przekładu A. Bosiacki, Wolters Kluwer, Warszawa 2017, s. 57.

55 Ibidem, s. 57-58. 
Drugi z wskazywanych przez R. Sarkowicza sposobów podejścia do presupozycji łączy się z przyjęciem dynamicznego ujęcia wykładni. Jako że znaczenie tekstu jest tu mniej stabilne, to ewolucji mogą również podlegać odtwarzane presupozycje. W Poziomowej interpretacji tekstu prawnego znajdujemy tylko sygnalizacyjne wskazanie możliwości takiego podejścia, przy czym czytamy, że prowadzi ono do swoistej podmiany autora, którym może być „np. aktualny prawodawca lub jakiś bliżej nieokreślony, ale współczesny interpretatorowi podmiot kierujący się określonymi celami lub wartościami”"56. Trzeba przy tym podkreślić, że wedle Sarkowicza na trzecim poziomie interpretacji nie odtwarzamy jakiegoś istniejącego idealnie świata norm, lecz właśnie ten konkretny i rzeczywisty. Nie chodzi więc o świat kreowany przez tekst, lecz o świat, w którym tekst powstał lub - przy ujęciu dynamicznym - świat, w którym tekst funkcjonuje.

Trop łączący problematykę presupozycji z dynamicznym ujęciem wykładni znajdujemy również w rozważaniach Andrzeja Batora. Wrocławski teoretyk zwraca uwagę, że przy interpretacji adaptacyjnej dochodzi do przesunięcia zainteresowania z presupozycji decyzji podejmowanych przez prawodawcę na presupozycje rozstrzygnięć interpretacyjnych dokonywanych przez prawni$\mathrm{ka}^{57}$. A zatem presupozycje te nie dotyczą już świata prawodawcy (ś3), lecz prawniczego sposobu rekonstruowania świata tekstu (ś1).

Po tej dłuższej charakterystyce presupozycjalnego poziomu wykładni możemy powrócić do pytania o to, czy znajduje się tam miejsce na ulokowanie takich elementów opisu ś1 jak część wewnętrzna i zewnętrzna, czy jak występowanie lub niewystępowanie kontratypu w art. 213 kodeksu karnego. Otóż przy rekonstruowaniu presupozycji w duchu statycznej teorii wykładni takiego miejsca tam bez wątpienia nie ma, a to dlatego, że presupozycje te nie odsłaniają świata tekstu, lecz świat, w którym tekst powstał. Kwestia ta wygląda natomiast mniej klarownie przy przyjęciu dynamicznej teorii wykładni. Presupozycje zmieniają wtedy bowiem swój przedmiot. Wydaje się jednak, że nawet $\mathrm{w}$ takiej wersji, w której rekonstrukcja poziomu presupozycjalnego dotyczy myślenia prawniczego, presupozycje te nie obejmują wskazywanych wyżej fragmentów ś1. Jakkolwiek dochodzi tu do zmiany przedmiotu, to rekonstruując tak ujmowane presupozycje nie odtwarzamy świata tekstu (ś1), lecz raczej pewne przesłanki, jakimi kierują się „cisi współkonstruktorzy” owego świata, czyli jego interpretatorzy. Pomocne są tu ustalenia na temat presupozycji

56 R. Sarkowicz, Poziomowa ..., s. 174.

57 A. Bator, Poziomowa ..., s. 283-284. 
rozumowań prawniczych, poczynione przez Jerzego Wróblewskiego ${ }^{58}$. Łódzki teoretyk wyodrębnia trzy grupy presupozycji takich rozumowań, tj. dotyczące reguł, faktów i wartości. Otóż przeprowadzona przez Wróblewskiego analiza reguł należących do poszczególnych typów pozwala stwierdzić, że ich treścią nie są elementy świata tekstu (ś1), lecz podstawowe założenia przyjmowane w rekonstruowaniu tegoż ś1. Dla przykładu, presupozycje dotyczące wartości nie polegają na odtworzeniu podstawowej aksjologii prawa, lecz na przyjęciu - między innymi - że „oceny są częścią racji uzasadniających decyzję interpretacyjną" ${ }^{59}$. Z kolei presupozycje faktu, a więc dotyczące ontologii, nie polegają na uznaniu podstawowych bytów z ś1, lecz - na przykład - na przyjęciu, że „istnieją reguły sformułowane w języku prawnym" ${ }^{60}$ lub że istnieje przyroda, społeczeństwo, człowiek oraz że obiekty te posiadają właściwe sobie cechy ${ }^{61}$. Obiekty te nie są jednak elementami ś1, lecz ulokowanymi w ś3 warunkami rekonstrukcji ś1-chodzi wszak o presupozycje f a k tó w. Wydaje się zatem, że nawet przy zmianie odniesienia presupozycji nie ma na presupozycjonalnym poziomie interpretacji miejsca na elementy wskazane w podanych wcześniej przykładach.

Jeśli jednak na wskazane elementy nie ma miejsca ani na poziomie dyrektywnym, ani na presupozycjonalym, to gdzie go szukać? W moim przekonaniu istnieje jeszcze trzeci kierunek poszukiwań, tj. przyjęcie, że poziom deskryptywny może być także ujmowany z perspektywy wewnętrznej. Gdyby przystać na to rozwiązanie, struktura poziomów interpretacji tekstu prawnego wyglądałaby następująco: 1) eksternalno-deskryptywny, 2) dyrektywny, 3) internalno-deskryptywny, 4) presupozycjonalny.

M. Zajęcki bardzo trafnie zwraca uwagę, że odróżnienie poziomu deskryptywnego od presupozycjonalnego jest kluczowe dla koncepcji R. Sarkowicza ${ }^{62}$. Otóż w moim przekonaniu konsekwentne podtrzymanie tego rozróżnienia wymaga przyjęcia istnienia internalno-deskryptywnego poziomu interpretacji. W przeciwnym razie istnieje duże ryzyko, że pewne elementy śl będziemy próbować ulokować na innych poziomach interpretacyjnych, zwłaszcza zaś na presupozycjonalnym.

\footnotetext{
J. Wróblewski, Presupozycje rozumowania prawniczego, Studia Prawno-Ekonomiczne 1986/ XXXVII, s. 7-21.

59 Ibidem, s. 18.

60 Ibidem, s. 17.

${ }^{61}$ Ibidem, s. 19-20.

62 M. Zajęcki, Presupozycje tekstu ..., s. 86-87.
} 
Podajmy jeszcze jeden przykład. W art. 60 kodeksu cywilnego znajdujemy sformułowaną w sposób nawiasowy definicję legalną terminu „oświadczenie woli":

Z zastrzeżeniem wyjątków w ustawie przewidzianych, wola osoby dokonującej czynności prawnej może być wyrażona przez każde zachowanie się tej osoby, które ujawnia jej wolę w sposób dostateczny, w tym również przez ujawnienie tej woli w postaci elektronicznej (oświadczenie woli).

Jak podkreśla się w literaturze, definicja ta jest dosyć skąpa i wymaga dookreślenia przez prawoznawstwo. Jako wynik takiej współkreującej pracy jurysprudencji przyjmuje się między innymi, że warunkiem uznania jakiegoś zachowania za złożenie oświadczenia woli jest jego dopuszczenie się w sposób swobodny i racjonalny. Mamy zatem dwa opisy przedmiotu ze świata tekstu prawnego (ś1) - jeden „surowy”, zewnętrzny, zaś drugi, bogatszy i pełniejszy, bo uwzględniający pracę doktryny. Zauważmy jednak, że wciąż mówimy o jednym i tym samym elemencie świata tekstu, zmienia się tylko stopień jego rozpoznania. Wskazany wyżej, sformułowany w doktrynie warunek nie jest presupozycją tekstu prawnego ani też presupozycją rozumowania prawniczego, lecz dookreśleniem elementu świata, jaki w tekście prawnym funkcjonuje, tj. świata konstruktów prawnych. Nie wyklucza to natomiast w żaden sposób tego, że warunkowi temu, podobnie jak explicite sformułowanym w tekście prawnym cechom oświadczenia woli, można przypisać określone presupozycje antropologiczne (w terminologii R. Sarkowicza - ontologiczne) ${ }^{63}$.

Dookreślające poznawanie ś1 przez jurysprudencję zawsze odbywa się w oparciu o presupozycje rozumowań prawniczych, a czasem również z wykorzystaniem presupozycji tekstu prawnego, jednak nie sprowadza się do odsłaniania tychże presupozycji. Rozpoznanie jakiejś właściwości ś3 może być argumentem na rzecz określonego rozumienia danego elementu ś1, jednak nie zastąpi tegoż rozumienia.

\section{Argument odwołujący się do metaforyki biblijnej}

Ostatni z powodów, dla których warto wyodrębnić poziom internalno-deskryptywny, ma nieco inną naturę niż te podane wcześniej. O ile bowiem do tej pory odwoływałem się do argumentów analitycznych, o tyle tutaj chciałbym

${ }_{63}$ Zob.: R. Zyzik, Obraz czlowieka..., s. 68-120 oraz podana tam literatura. Jakkolwiek autor ten nie nawiązuje do koncepcji R. Sarkowicza, to posługuje się pojęciem presupozycji, odnosząc je do funkcjonującego w polskim prawie cywilnym sposobu rozumienia terminu „oświadczenie woli”. 
wstąpić na grunt bardziej miękki i zawodny, związany z wykorzystaniem metaforyki biblijnej w omawianej koncepcji. Otóż czytamy, że poziomy interpretacyjne układają się nieco podobnie, jak ma to miejsce w lekturze Pisma Świętego, gdzie po warstwach literalnej i moralnej osiągamy to, co najważniejsze, tj. poziom mistyczny ${ }^{64}$. Zauważmy, że rolę etapu związanego z największym wtajemniczeniem i z osiągnięciem stanu wiary pełni tu poziom presupozycjonalny. Czy jednak rzeczywiście ujmowanie badania presupozycji jako kulminacyjnego momentu poznania prawniczego jest przekonujące? Zadanie rekonstrukcji presupozycji tekstu prawnego wydaje się fascynującym przedsięwzięciem dla historyków próbujących dowiedzieć się czegoś o przeszłości na podstawie analizy dawnych aktów prawnych. W stosunku jednak do pracy prawnika czy filozofa prawa interpretującego współcześnie obowiązujący tekst prawny nietrudno wyobrazić sobie sceptycyzm co do tego, czy w istocie można w ten sposób dowiedzieć się o rzeczywistym świecie czegoś, co skądinąd nie byłoby wiadome. Sceptyk mógłby bowiem zapytać o to, czy znamy jakiś przykład takiego badania współcześnie obowiązujących aktów prawnych, które przyniosłoby nieznane wcześniej wiadomości o otaczającym nas świecie. Wątpliwość tę można próbować oddalić poprzez odwołanie do argumentu wskazującego na konieczność zapośredniczania poznania. Dla przykładu, pokonywanie swoistej drogi okrężnej oraz poszukiwanie prawdy o ludziach i społeczeństwach poprzez badanie różnych wytworów kulturowych charakterystyczne jest dla podejścia hermeneutycznego ${ }^{65}$. Radykalizacji tego argumentu dostarcza perspektywa psychoanalityczna z właściwą sobie hermeneutyką podejrzeń, skłaniającą do głębokiej nieufności wobec powszechnie przyjmowanego obrazu rzeczywistości. W takim ujęciu rekonstruowanie ukrytych w tekście prawnym presupozycji jawi się jako sposób tropienia i demaskowania przyjmowanych w społeczeństwie mitów. I tak na przykład $\mathrm{z}$ faktu zagrożenia w polskim kodeksie karnym znacznie surowszą sankcją za czyn polegający na podrabianiu i przerabianiu pieniędzy niż za ciężkie pobicie człowieka można próbować wyprowadzać presupozycję, że rzeczywista, nieświadomie funkcjonująca w naszym społeczeństwie aksjologia wygląda daleko inaczej niż ta powszechnie uświadamiana, lokująca godność ludzką w centrum. Podobny wniosek może się nasuwać przy zestawieniu łagodnych sankcji przewidzianych za naruszenie czci z surowszymi karami za przestępstwa przeciwko

${ }^{64}$ R. Sarkowicz, Poziomowa ..., s. 62-63.

65 Zob. L. Kleszcz, Boczne drogi. Z genealogii filozofii hermeneutycznej, Oficyna Wydawnicza Arboretum, Wrocław 2004, s. 5-7. 
mieniu. Zauważmy jednak, że ewentualne przewartościowanie faktycznej roli idei godności, dokonane jako wynik badania presupozycji byłoby czymś zasadniczo odmiennym od zakwestionowania znaczenia zasady poszanowania godności ludzkiej w dyskursie dogmatycznoprawnym. W pewnym sensie byłoby to już wyjście poza perspektywę prawniczą, albowiem z wewnętrznego, jurydycznego punktu widzenia fundamentalna rola poszanowania godności ludzkiej jest czymś niepodważalnym. Jednak inaczej już wygląda sytuacja socjologa, który w oparciu o analizę tekstu prawnego może stwierdzić, że w danym społeczeństwie godność ludzka jest znacznie niżej ceniona niż oficjalnie się tam twierdzi.

Tym samym docieramy do rdzenia argumentu odwołującego się do wykorzystanej metaforyki biblijnej. Otóż na podniesione wyżej sceptyczne pytanie o to, czy istnieje możliwość zdobywania wiedzy o współczesnym społeczeństwie poprzez analizę presupozycji aktów prawych, należy - w moim przekonaniu - odpowiedzieć twierdząco. A zatem badanie presupozycji tekstów prawnych może być interesującym źródłem wiedzy o współczesnym społeczeństwie. Jednak wiedza ta będzie często wyprowadzała poza wewnętrzny, prawniczy ogląd systemu prawa i w tym sensie podaję w wątpliwość zasadność łączenia jej z metaforyką wiary i najwyższego wtajemniczenia.

W tym kontekście znamienny wydaje się przykład podany przez R. Sarkowicza. Krakowski teoretyk odpowiada bowiem wprost na postawione wyżej pytanie o potencjalną owocność badania koncentrującego się na rekonstruowaniu presupozycji tekstów prawnych. Wskazuje mianowicie na ruch studiów krytycznych nad prawem (Critical Legal Studies) jako na wzorcowy przykład podejścia skupiającego się na interpretacji presupozycjonalnej ${ }^{66}$. Jak wiadomo, demaskowanie ideologicznych założeń porządku prawnego oraz poszukiwanie tkwiących w nim aksjologicznych napięć czy sprzeczności stanowi istotną część programową tego ruchu ${ }^{67}$. Przy czym - co istotne z punktu widzenia jego adekwatności względem koncepcji interpretacji poziomej - w przeciwieństwie do realizmu prawnego ruch ten koncentruje się na badaniu tekstów prawnych, tak współcześnie obowiązujących, jak i historycznych ${ }^{68}$. Co ciekawe, przykład CLS potwierdza wskazany wyżej związek między koncentrowaniem się na badaniach presupozycji a pozostawaniem pod wpływem tradycji hermeneutyki

\footnotetext{
${ }_{66}$ R. Sarkowicz, Poziomowa..., s. 172.

${ }^{67}$ R. Sarkowicz, ,, Critical Legal Studies” - nowy ruch w amerykańskiej jurysprudencji, Państwo i Prawo 1987/3, zwł. s. 98-100.

68 Ibidem, s. 103.
} 
podejrzeń $^{69}$. Zauważmy jednak, że ów ruch, podany jako paradygmatyczny przykład realizacji programu badawczego koncentrującego się na presupozycjonalnej analizie prawa, ma zarazem olbrzymi potencjał dekonstrukcyjny. Podważanie takich elementów prawniczej perspektywy jak postrzegania prawa jako spójnego systemu czy jak wiara w istnienie swoistych rozumowań prawniczych stanowi bowiem podstawowe ustalenia tego kierunku prawoznawstwa ${ }^{70}$.

Jakkolwiek wyprowadzanie wniosku generalizującego na podstawie jednego przykładu jest metodologicznie wadliwe, to trudno nie postawić pytania o to, czy nie jest tak, że koncentrowanie się na badaniu presupozycji tekstu prawnego, skądinąd wartościowe i potrzebne, wyprowadza poza wewnętrzny, prawniczy punkt widzenia? Innymi słowy, czy nie jest tak, że poziom presupozycji jako etap najwyższego wtajemniczenia prowadziłby raczej do niewiary niż wiary w prawo? Podkreślmy, nie chodzi tu o podważanie zasadności zajmowania się poziomem presupozycji ani jego wartościowości dla poznania prawniczego, lecz o kwestionowanie łączenia rozpoznawania presupozycji z ostatnim, najwyższym stopniem wtajemniczenia w wiedzę prawniczą.

Na gruncie koncepcji poziomowej jest bezsporne, że rekonstruowanie presupozycji może być cenne nie tylko dla historyka czy socjologa, lecz również dla prawnika-praktyka ${ }^{71}$. Jak bowiem zwraca uwagę R. Sarkowicz, niektóre istotne dla stosowania prawa pojęcia, jak na przykład równości ludzi, nie są w tekście prawnym zdefiniowane, można je natomiast odtwarzać na podstawie presupozycji przepisów dotyczących przestępstwa naruszającego tę równość (w tym kontekście podany jest art. 274 kodeksu karnego z 1969 r. dotyczący obrażania na tle narodowościowym, etnicznym lub rasowym, którego współczesnym odpowiednikiem jest art. 257 kodeksu karnego z 1997 r. $)^{72}$. Innego przykładu dostarcza Ronald Dworkin argumentujący, że od rodzaju uzasadnienia, jakie sędziowie będą przypisywać prawu do swobody wypowiedzi, zależy sposób interpretacji tegoż prawa, w szczególności rozstrzyganie co do jego zakresu ${ }^{73}$. Zauważmy jednak, że w obu podanych przykładach ostatecznym celem nie jest znalezienie presupozycji (tj. dokładniejsze poznanie ś3),

${ }^{69}$ Idem, Ruch krytyczny w amerykańskiej teorii prawa, w: M. Jaskólski (red.), Z zagadnień filozofii społecznej. Zapiski myśli humanistycznej. Sens, nakładem Uniwersytetu Jagiellońskiego, Kraków 1989, s. 81.

70 Ibidem, s. 87.

71 R. Sarkowicz, Poziomowa..., s. 170.

72 Ibidem, s. 170.

73 R. Dworkin, Freedom's Law. The Moral Reading of The American Constitution, Harvard University Press, Cambridge, Massachusetts 1996, s. 199. 
lecz dokonanie lepszego rozpoznania światów wynikających z tekstu prawnego (ś1 i ś2). Co więcej, wydaje się, że cały olbrzymi Dworkinowski projekt integracyjnej filozofii prawa może być postrzegany jako przykład ilustrujący istotność presupozycji w sposób inny niż robi to CLS, tj. taki, który obliczony jest na wzmacnianie i optymalizowanie świata konstruktów prawnych, nie zaś na jego dekomponowanie.

Potwierdzenie zasadności przyjęcia wyłaniającego się tu rozróżnienia na dwa odmienne podejścia do rekonstrukcji presupozycji znajdujemy w artykule Levels of Interpretation of a Legal Text. R. Sarkowicz mówi tam explicite o dwóch różnych sposobach odtwarzania poziomu ideologicznego (występującego w tym tekście zamiast poziomu presupozycji), z których pierwszy przyjmuje założenie braku sprzeczności w aksjologii porządku prawnego, zaś drugi - przeciwnie, ukierunkowany jest na ich poszukiwanie ${ }^{74}$. Mówiąc inaczej, jeden $\mathrm{z}$ nich prowadzony jest $\mathrm{w}$ duchu hermeneutyki zaufania, zaś drugi - hermeneutyki podejrzeń. Pierwszy prowadzi do optymalizacyjnego, ,naprawczego” interpretowania tekstu prawnego, przezwyciężającego napotykane przy literalnym odczytaniu „pęknięcia”, zaś drugi do dekonstrukcji spójności ś1 i ś2. Wydaje się więc, że tylko drugie z tych ujęć może występować jako ostatni etap interpretacji, będąc jednak przy tym raczej aktem niewiary niż wiary w prawo. Natomiast pierwsze z ujęć zdaje się prowadzić do etapu kolejnego - odtworzenia spójnego obrazu ś1 i ś2.

Jeśli powyższe rozważania są poprawne, to zasadnym jest przyjąć, że ów najważniejszy, kulminacyjny moment stopniowego wtajemniczania w świat prawa przypada nie na poziom presupozycji, lecz na poziom internalno-deskryptywny. Rozpoznawanie presupozycji byłoby w tym ujęciu bardzo ważnym, ale jednak nie kulminacyjnym etapem poznania prawniczego. Gdyby zgodzić się na takie postawienie sprawy, to schemat interpretacji wyglądałby następująco: a) poziom eksternalno-deskryptywny, b) poziom dyrektywny, c) poziom presupozycji, d) poziom internalno-deskryptywny.

W polskim prawoznawstwie metaforyką religijną posługiwał się Artur Ko$z^{7 a k}$. Autor ten uczynił interesujące rozróżnienie między Znawcą a Wyznawcą prawa. Choć obaj mają do czynienia z tymi samymi tekstami prawnymi, to czy-

\footnotetext{
R. Sarkowicz, Levels of Interpretation..., s. 109.
}

75 A. Kozak, Dylematy prawniczej dyskrecjonalności. Między ideologia polityki a teoria prawa, w: W. Staśkiewicz, T. Stawecki (red.), Dyskrecjonalność w prawie, Lexis Nexis, Warszawa 2010, s. 58-80. Zob. też: A. Kozak, Granice prawniczej władzy dyskrecjonalnej, Kolonia Limited, Wrocław 2002, s. 70-73; M. Pichlak, Artura Kozaka cierpliwość wobec prawa, Filozofia Publiczna i Edukacja Demokratyczna 2014/3/1, s. 226-242. 
tają je na dwa radykalnie odmienne sposoby. Znawca dekonstruuje prawo, dokonując jego opisu w kategoriach zewnętrznych dla samego prawa. Wyznawca zaś, niezależnie od krytyki poszczególnych elementów prawa, zasadniczo je afirmuje i broni wewnętrznego, jurydycznego spojrzenia na prawo. Wydaje się, że postawa taka dobrze koresponduje z tym, co próbowałem tutaj zarysować jako poziom internalno-deskryptywny.

\section{Zakończenie}

Zdaję sobie sprawę, że zaproponowany w niniejszym artykule sposób odczytania teorii Ryszarda Sarkowicza nie jest jedynym możliwym. Powyższe rozważania nie są niczym innym niż swoistym raportem z własnych prób ułożenia sobie tej fascynującej koncepcji. Chciałbym zarazem podkreślić, że wprowadzone elementy modyfikujące (lub może tylko klarujące) są właściwie minimalne i można je sprowadzić do dwóch. Stanowią one zarazem dwie podstawowe konkluzje niniejszego artykułu. Po pierwsze, starałem się pokazać, że w interesującej mnie koncepcji istnieją przesłanki do różnych sposobów rozumienia deskryptywnego poziomu interpretacji prawniczej, tj. takiego sposobu, który łączy go tylko z perspektywą zewnętrzną, i takiego, który łączy go z perspektywą zewnętrzną i wewnętrzną. Podałem też powody, które - w moim przekonaniu - przemawiają za drugim z tych z rozwiązań. Po wtóre, wyciągnąłem konsekwencję $\mathrm{z}$ tego wyboru, proponując wyróżnić czwarty poziom interpretacji. Krok ten tylko pozornie jest radykalny. Po prostu zamiast mówić, że pierwszy poziom interpretacji wygląda inaczej z perspektywy zewnętrznej, a inaczej z wewnętrznej, proponuję je rozdzielić. Zauważmy, że R. Sarkowicz pisze o potrzebie powracania do odtwarzania ś1 po poznaniu ś2 i - przynajmniej pośrednio, tj. $\mathrm{w}$ takim zakresie, $\mathrm{w}$ jakim ś3 jest istotne dla odtworzenia ś2 - po poznaniu ś3. Kwestią czystej konwencji jest, czy ów obraz ś1, uzyskany po wtajemniczeniu w inne poziomy i daleko przez to przekształcony w stosunku do stanu początkowego, będziemy określać tym samym poziomem, ale przyjmującym inną postać, czy też poziomem innym. Trzeba przy tym podkreślić, że poziom deskryptywny jest jedynym spośród trzech, który występuje w postaci eksternalnej i internalnej zarazem. 


\section{Bibliografia}

Bator Andrzej, Poziomowa interpretacja tekstu prawnego, w: Andrzej Bator (red.), Wprowadzenie do nauk prawnych. Leksykon tematyczny, Wolters Kluwer, Warszawa 2016, s. 280-284.

Böckenförde Ernst-Wolfgang, Wizerunek czlowieka w świetle dzisiejszego porzadku prawnego, thum. Małgorzata Łukasiewicz, w: Krzysztof Michalski (red.), Człowiek w nauce współczesnej. Rozmowy z Castelgandolfo 1983, ĖDITIONS DU DIALOGUE, Paryż 1988, s. 115-125.

Dworkin Ronald, Freedom's Law. The Moral Reading of The American Constitution, Harvard University Press, Cambridge, Massachusetts 1996.

Gizbert-Studnicki Tomasz, Język prawny a obraz świata, w: Grażyna Skąpska (red.), Prawo w zmieniajacym się społeczeństwie, Wydawnictwo Adam Marszałek, Kraków 1992, s. $149-161$.

Kleszcz Leszek, Boczne drogi. Z genealogii filozofii hermeneutycznej, Oficyna Wydawnicza Arboretum, Wrocław 2004.

Kozak Artur, Granice prawniczej władzy dyskrecjonalnej, Kolonia Limited, Wrocław 2002.

Kozak Artur, Dylematy prawniczej dyskrecjonalności. Między ideologia polityki a teoria prawa, w: Wiesław Staśkiewicz, Tomasz Stawecki (red.), Dyskrecjonalność w prawie, Lexis Nexis, Warszawa 2010, s. 58-80.

Petrażycki Leon, Wstęp do nauki polityki prawa, oprac. Wiktor Leśniewski, Państwowe Wydawnictwo Naukowe, Warszawa 1968.

Petrażycki Leon, Polityka prawa cywilnego i ekonomia polityczna, tłum. Paweł Kosiński, redakcja naukowa, wstęp i uwspółcześnienie przekładu Adam Bosiacki, Wolters Kluwer, Warszawa 2017.

Pichlak Maciej, Artura Kozaka cierpliwość wobec prawa, Filozofia Publiczna i Edukacja Demokratyczna 2014/3/1, s. 226-242.

Popper Karl R., Wiedza a zagadnienie ciała i umystu. W obronie interakcji, thum. Tadeusz Baszniak, Książka i Wiedza, Warszawa 1998.

Sarkowicz Ryszard, ,,Critical Legal Studies”- nowy ruch w amerykańskiej jurysprudencji, Państwo i Prawo 1987/3, s. 96-104.

Sarkowicz Ryszard, Ruch krytyczny w amerykańskiej teorii prawa, w: Michał Jaskólski (red.), Z zagadnień filozofii społecznej. Zapiski myśli humanistycznej. Sens, nakładem Uniwersytetu Jagiellońskiego, Kraków 1989, s. 77-96.

Sarkowicz Ryszard, Poziomowa interpretacja tekstu prawnego, nakładem Uniwersytetu Jagiellońskiego, Kraków 1995.

Sarkowicz Ryszard, Levels of Interpretation of a Legal Text, Ratio Juris, March 1995/8/1, s. $104-112$.

Sarkowicz Ryszard, O rozumieniu spójności w interpretacji prawniczej, w: Teoria prawa. Filozofia prawa. Wspótczesne prawo i prawoznawstwo, Wydawnictwo Uniwersytetu Mikołaja Kopernika, Torun 1998, s. 263-271.

Sarkowicz Ryszard, Uwagi o wspótczesnej interpretacji prawniczej, w: Sławomira Wronkowska (red.), Polska kultura prawna a proces integracji europejskiej, Zakamycze 2005, s. 11-30.

Smolak Marek, Presupozycje ontologiczne tekstu prawnego, Ruch Prawniczy, Ekonomiczny i Socjologiczny 2011/4, s. 41-51.

Smolak Marek, Kilka uwag do artykułu Maurycego Zajęckiego „Presupozycje surowe i instytucjonalne: Próba poszerzenia koncepcji presupozycji tekstu prawnego Marka Smolaka”, Ruch Prawniczy, Ekonomiczny i Socjologiczny 2013/LXXV/2, s. 281-284. 
Wróblewski Jerzy, Presupozycje rozumowania prawniczego, Studia Prawno-Ekonomiczne 1986/XXXVII, s. 7-21.

Zajęcki Maurycy, Presupozycje tekstu jako narzędzie analizy w naukach historyczno prawnych $i$ w teorii prawa, w: Piotr Orlik, Krzysztof Przybyszewski (red.), Filozofia a sfera publiczna, Uniwersytet im. Adama Mickiewicza w Poznaniu, Wydawnictwo Naukowe Instytutu Filozofii, Poznań 2012, s. 67-94.

Zajęcki Maurycy, Presupozycje surowe i presupozycje instytucjonalne. Próba poszerzenia koncepcji presupozycji tekstu prawnego Marka Smolaka, Ruch Prawniczy, Ekonomiczny i Socjologiczny, 2013/2, s. 265-279.

Zgoliński Igor, Zniesławienie w polskim prawie karnym. Zagadnienia teorii i praktyki, Wolters Kluwer, Warszawa 2013.

Zieliński Maciej, Wykładnia prawa. Zasady, reguły, wskazówki, Wolters Kluwer, Warszawa 2010.

Ziembiński Zygmunt, Ryszard Sarkowicz: Poziomowa interpretacja tekstu prawnego (recenzja), Państwo i Prawo 1995/9, s. 91-92.

Zirk-Sadowski Marek, Hermeneutyka a problemy filozofii prawa, Studia Prawno-Ekonomiczne 1982/XXIX, s. 7-25.

Zyzik Radosław, Obraz człowieka w teorii oświadczeń woli. Perspektywa neuronauki poznawczej i psychologii, Wydawnictwo WAM, Kraków 2016.

Paweł JABŁOŃSKI

\section{ON THE DESCRIPTIVE LEVEL OF INTERPRETATION OF A LEGAL TEXT}

( Sum mary)

The aim of the article is the analysis of Ryszard Sarkowicz's theory of levels of interpretation of a legal text. This theory, on the one hand, is aptly indicated as one of the most original and valuable achievements of Polish theory of law, and, on the other hand - a bit paradoxically - it is extremely rarely discussed. In my article I show one element of tension that you can see in the description of what R. Sarkowicz calls the descriptive level of interpretation. It seems that sometimes this level is associated only with the external perspective, and other times with external and internal ones. In the following subsections, I present arguments for the second of these solutions. At the end of the article I show a consequence of this choice. It consists in transformation of the concept by distinguishing an additional level of interpretation - descriptive one in the internal point of view.

Keywords: Ryszard Sarkowicz; levels of interpretation of a legal text; internal point of view 